\title{
Induction of Apoptosis in MRC-5, Diploid Human Fetal Lung Cells after Infection with Human Coronavirus OC43
}

\author{
ARLENE R. COLLINS \\ Department of Microbiology, State University of New York at Buffalo, Buffalo NY USA 14214
}

\section{INTRODUCTION}

Human coronaviruses $(\mathrm{HCoV})$ cause upper respiratory tract infections manifested by symptoms of the common cold including rhinitis, tussis, fever, headache and myalgia (Hruskova et al 1990). HCoV respiratory illness is primarily virus-mediated; immunologic events have not been postulated to play a role (Makela et al 1998). Evidence showing the presence of viral genome in spinal fluid and brain suggests that $\mathrm{HCoV}$ may play an etiologic role in multiple sclerosis (Stewart et al 1992, Cristallo et al 1997). However, the pathogenesis of $\mathrm{HCoV}$ infections is poorly understood. In human embryonic tracheal organ cultures, $\mathrm{HCoV}$ causes a slow patchy destruction of the ciliated epithelial cells and in respiratory epithelial tissue cultures, the cytopathic effect is subtle, evident only by vacuolization and spindling.

Since apoptosis is a mechanism of cell death for other coronaviruses such as transmissible gastroenteritis virus (TGEV) (Eleouet et al 1998) and mouse hepatitis virus (MHV) (An et al 1999), we examined infected MRC-5 cells with $\mathrm{HCoV}$ and examined the cells for changes associated with programmed cell death. DNA fragmentation and formation of apoptotic bodies was observed in cells infected with HCoV-OC43. 
2. MATERIALS AND METHODS

\subsection{Viruses and Cells}

$\mathrm{HCoV}-229 \mathrm{E}$ and $\mathrm{HCoV}-\mathrm{OC} 43$ strains that had been repeatedly passaged in M-7 and MRC-5, human lung fetal cells were used in this study.

\subsection{Assessment of DNA Degradation}

HCoV-OC43-infected and uninfected MRC- 5 cells $\left(2 \times 10^{6}\right.$ cells $)$ were harvested after six days of exposure to virus. DNA was isolated with DNAzol (Molecular Research Center, Cincinnati, OH), incubated with RNAse A $(1 \mu \mathrm{g} / \mathrm{ml})$ at $50^{\circ} \mathrm{C}$ for $1 \mathrm{~h}$, and then loaded onto a $1.2 \%$ agarose gel containing ethidium bromide. After electrophoresis, the gel was photographed and examined for the presence of DNA laddering (Jan and Griffin 1999).

\subsection{Visualization of Apoptotic Nuclei by Ethidium Bromide Staining}

To detect DNA condensation and fragmentation, the cells were fixed in cold acetone, stained for 10 minutes with $100 \mu \mathrm{g} / \mathrm{ml}$ ethidium bromide in PBS and washed twice in PBS. Microscopic visualization of apoptotic nuclei was performed by light microscopy using epiilumination and a filter for fluorescein.

\section{$2.4 \quad$ Immunofluorescence}

After fixing the cells in cold acetone, viral antigen was detected by indirect immunofluorescent staining using monoclonal antibody 4B6.1 to $\mathrm{HCoV}-\mathrm{OC} 43$ nucleocapsid as the primary antibody followed by fluoresceinconjugated goat anti-mouse immunoglobulin (Vector, Burlingame CA). 


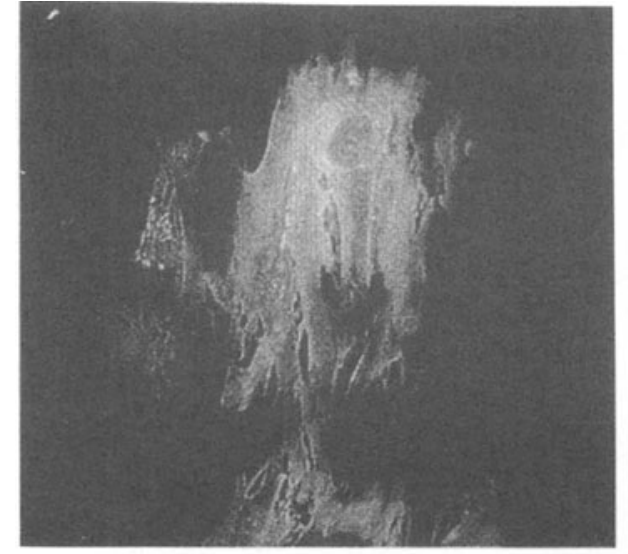

$\mathbf{A}$

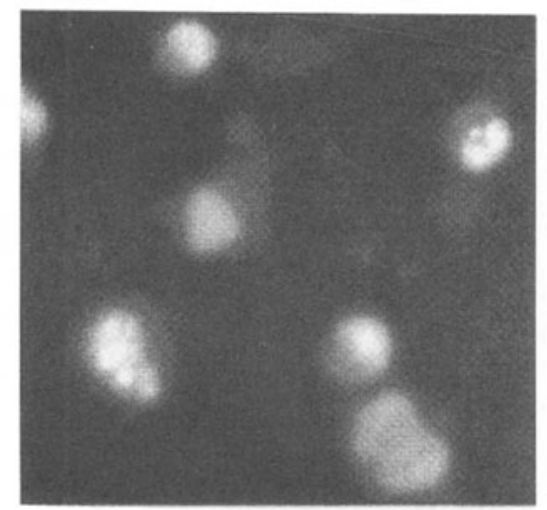

B

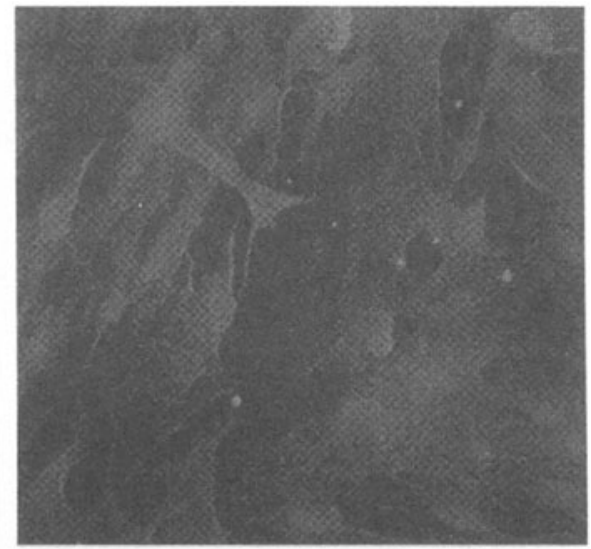

C

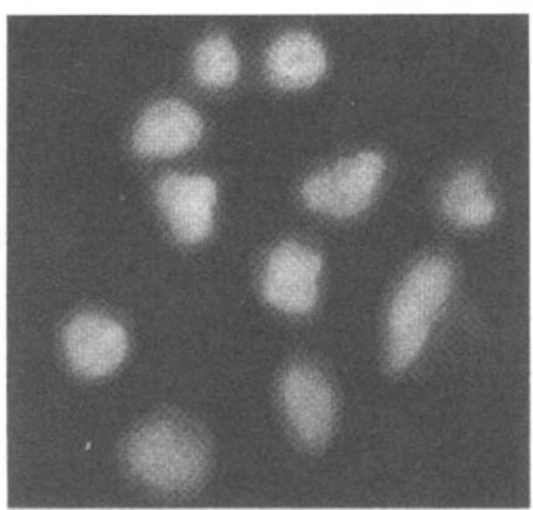

D

Figure 1. Viral antigen expression and induction of apoptosis in MRC-5 cells infected with $\mathrm{HCoV}-\mathrm{OC} 43$ at a moi of 1 and incubated at $33^{\circ} \mathrm{C}$. Panels $\mathrm{A}$ and $\mathrm{C}$ : Immunofluorescent staining for viral nucleocapsid antigen with $\mathrm{mAb} 4 \mathrm{~B} 6.1$. Panels $\mathrm{B}$ and $\mathrm{D}$ : Ethidium bromide staining for DNA fragmentation. Panels A and B are infected cells. Panels $\mathrm{C}$ and D are mockinfected cells. 


\section{RESULTS}

In order to assess the cytologic changes in MRC-5 cells after infection by $\mathrm{HCoV}-\mathrm{OC} 43$, we exposed semi-confluent monolayer of cells to virus at a moi of 1 and incubated the cells at $33^{\circ} \mathrm{C}$. Three days after infection, swollen, rounded, granular cells were observed. These cells showed immunuofluorescent staining for viral nucleocapsid (Fig1 A). By six days post-infection, many cells became detatched and those cells remaining were further enlarged and granular. The adherent cells were fixed in acetone and the nuclear DNA was stained with ethidium bromide. We observed DNA condensation and formation of apoptotic bodies in the nucleus (Fig 1B). Further confirmation of DNA fragmentation was obtained by extracting the DNA from a pool of detached and adherent cells infected for six days and assessing for DNA ladder formation after gel electrophoresis. Fragmentation was present in DNA from $\mathrm{HCoV}-\mathrm{OC} 43$-infected cells, but not in mock-infected cells (Fig.2). Interestingly, DNA fragmentation was observed at six days post-infection indicating that the onset of apoptosis was two to three days earlier, coinciding with the time of maximum viral yield. The yield of infectious $\mathrm{HCoV}-\mathrm{OC} 43$ was greater in the cell-associated than in the cell-free virus fraction suggesting that accumulation of virus or viral protein(s) caused induction of apoptosis. In HCoV-229E infected MRC-5 cells maximum virus yield was fivefold less and was higher in the cell-free than in the cell-associated fraction. The viral titer reached its peak earlier in $\mathrm{HCoV}-229 \mathrm{E}$ than in HCoV-OC43 infection and the nucleus did not appear to undergo apoptotic condensation.

Table 1. Characteristics of HCoV-OC43-infected MRC-5cells

\begin{tabular}{ll}
\hline Property & Characteristic \\
\hline Cytopathic effect & Granular degeneration, enlargement \\
Viral titer & $2.8 \times 10^{6} \mathrm{pfu} / \mathrm{ml}$ \\
Maturation and release & More cell associated \\
DNA fragmentation & yes \\
Cell death & apoptosis \\
\hline
\end{tabular}

\section{DISCUSSION}

We found evidence of apoptotic death in MRC-5 cells six days after infection with $\mathrm{HCoV}-\mathrm{OC} 43$, in cells that contained large amounts of intracellular virus. The events that triggered apoptosis have yet to be determined. In MHV-induced apoptosis, the coronavirus $\mathrm{E}$ protein alone was responsible (An et al 1999). The $\mathrm{E}$ protein of MHV, found on gene5, is expressed from an internal ribosome entry structure (IRES) which could 


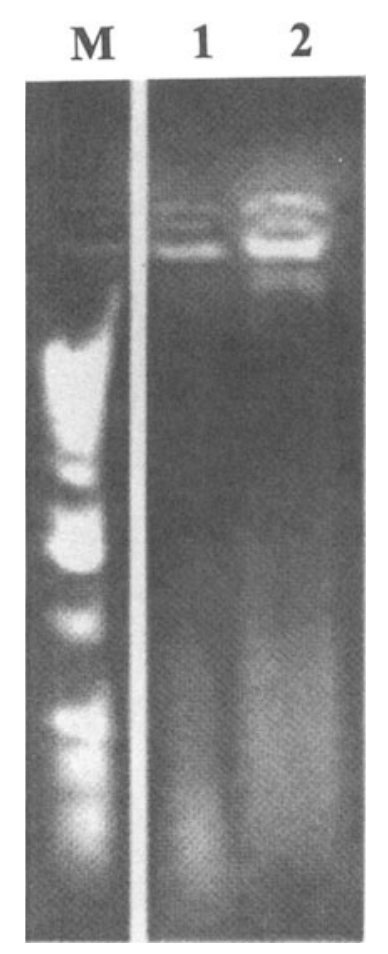

Figure 2. Gel electrophroresis of DNA for assessment of fragmentation in MRC-5 cells. Lane M: $1 \mathrm{~kb}$ markers, lanel: mock, lane 2: infected with HCoV-OC43.

account for its accumulation leading to induction of apoptosis (Jendrach et al 1999). Induction of apoptosis by HCoV-OC43 may play a role in evasion of immune recognition and suppression of host-mediated responses, events that favor establishment of persistent infection. Other mechanisms favoring persistence include protection of the infected cell from complementmediated lysis by regulators of complement activation and antigenic variation of the virus (Varsano et al 1995, Collins et al 1986, Arbour et al 1999). In comparison, HCoV-229E infection in MRC-5 cells proceeds more rapidly without programmed cell death. $\mathrm{HCoV}-229 \mathrm{E}$ infected cells may be more sensitive to anti-apoptotic BCL-2 proteins (Bonati et al 1996). Interestingly in a study of primary infections showing a seroconversion to the virus, $\mathrm{HCoV}-229 \mathrm{E}$ acute respiratory disease included conjunctivitis and lymphadenitis, symptoms that were not associated with $\mathrm{HCoV}-\mathrm{OC} 43$ illness (Hruskova et al 1990). Further examination of $\mathrm{HCoV}$ pathogenesis is important in the management of childhood asthma and older people with chronic illnesses. 


\section{ACKNOWLEDGEMENTS}

The author wishes to thank Drs. Shinpei Ohki and .Michio Ito for many helpful discussions.

\section{REFERENCES}

An, S., Chen, C-J., Xin, Y., Leibowitz, J.L. and S. Makino. 1999. Induction of apoptosis in murine coronavirus-infected cultured cells and demonstration of $\mathrm{E}$ protein as an apoptosis inducer. J. Virol. 73: 7853-7859.

Arbour, N., Côté, G., Lachance, C., Tardieu, M., Cashman, N.R., and P. J. Talbot. 1999. Acute and Persistent Infection of Human Neural Cell Lines by Human Coronavirus OC43. J. Virol. 73: 3338-3350.

Bonati, A., Albertini, R., Garau, D., Pinelli, S., Lunghi, P., Almici, C., Carlo-Stella, C., Rizzoli, V., and P. Dall'aglio. 1996. BCL2 oncogene protein expression in human hematopoietic precursors during fetal life. Exp.Hematol. 24:459-465.

Collins, A.R. and O. Sorensen. 1986 Regulation of viral persistence in human glioblastoma and rhabdomyosarcoma cells infected with coronavirus OC43. Microbial Path. 1: 573-583.

Cristallo, A., Gambaro, F., Biamonte G., Ferrante, P., Battaglia, M. and P.M. Cereda. 1997. Human coronavirus polyadenylated RNA sequences in cerebrospinal fluid from multiple sclerosis patients. New Microb. 20: 105-114.

Eleouet,J., Chilmonczyk,S., Besnardeau,L., and H. Laude. 1998. Transmissible gastroenteritis coronavirus induces programmed cell death in infected cells through a caspase-dependent pathway. J.Virol. 66: 4918-4924.

Fischer, F., Stegen, C.R., Masters, P.S. and W.A. Samsonoff. 1998. Analysis of constructed E gene mutants of mouse hepatitis virus confirms a pivotal role for E protein in coronavirus assembly. J.Virol. 72: 7885-7894.

Hruskova, J.,Heinz, F., Svandova, E. and S. Pennigerova. 1990. Antibodies to human coroanviruses 229e and OC43 in the population of C.R. Arch. Virol. 34: 346-352.

Jan, J. and D.E. Griffin. 1999. Induction of apoptosis by Sindbis virus occurs at cell entry and does not require virus replication. J.Virol. 73: 10296-10302.

Jendrach, M., Theil. V., and S. Siddell. 1999. Characterization of an internal ribosome entry site within mRNA5 of murine hepatitis virus. Arch.Virol. 144: 921-933.

Makela, M.J., Puhakka, T., Ruuskanen, O., Leinonen, L.M., Saikku, P., Kimpimaki, M., Blomqvist, S., Hyypia, T. and P. Arstila. 1998. Viruses and bacteria in the etiology of the common cold. J. Clin. Microbiol. 36: 539-542.

Stewart, J.N., Mounir,S. and PJ. Talbot. 1992. Human coronavirus gene expression in the brains of multiple sclerosis patients. Virol. 191:502-505.

Varsano, S., Frolkis, I., and D. Ophir. 1995. Expression and distribution of cell-membrane complement regulatory glycoproteins along the human respiratory tract. Am. J. Respir. Crit. Care Med. 152: 1087-93. 